\title{
New cranial material of the acanthothoracid placoderm Palaeacanthaspis vasta from the Lower Devonian of Podolia-phylogenetic and taxonomic significance
}

Vincent Dupret, Hubert Szaniawski, Marek Dec, and Piotr Szrek

Acta Palaeontologica Polonica 66 (2), 2021: 337-347 doi:https://doi.org/10.4202/app.00857.2020

The Early Devonian vertebrates of Podolia in Ukraine are well known thanks to the material of the basal arthrodire placoderm genus Kujdanowiaspis, originally mentioned by Brotzen in 1934. The anatomical fame of Kujdanowiaspis brought by Erik Stensiö almost eclipsed the presence of the acanthothoracid placoderm Palaeacanthapsis vasta in the underlying beds, with the original material of $P$. vasta being less well preserved and abundant than that of Kujdanowiaspis. Here we describe a newly discovered specimen of the acanthothoracid $P$. vasta from the Lochkovian of Podolia (Ukraine). The specimen, although incomplete, is very well preserved in three dimensions and allows a thorough description of its external morphology, which is compared to that of Romundina stellina and other well-known Acanthothoraci. A phylogenetic analysis is performed and the acanthothoracid nature of Palaeacanthaspis is confirmed. However, the position of Palaeacanthaspis within the Acanthothoraci remains uncertain, and its resemblance with Romundina could be due to either synapomorphies or symplesiomorphies. Similarities and differences between the two forms are exposed, and lead to the lack of synonymy at the specific level. Generic synonymy is also questioned for the first time but remains equivocal.

Key words: Placodermi, Acanthothoraci, neurocranium, Lochkovian, Devonian, Podolia, Ukraine.

Vincent Dupret [vincent.dupret@ebc.uu.se],

Evolutionsbiologiskt centrum (EBC), Uppsala

Universitet, Norbyvägen 18A-752 36 Uppsala, Sweden;

and Department of Applied Mathematics, Research

School of Physics, College of Sciences, Australian

National University, Mills Road, Canberra ACT 2601,

Australia. Hubert Szaniawski [szaniaw@twarda.pan.plszaniaw@twarda.pan.pl], Institute of

Palaeobiology, Polish Academy of Sciences, Twarda 51/55, 00-818 Warsaw, Poland.

Marek Dec [mdec@wp.pl] and Piotr Szrek [PSZR@pgi.gov.pl], Polish Geological Institute-National Research Institute, Rakowiecka 4, 00-975 Warsaw, Poland. 
This is an open-access article distributed under the terms of the Creative Commons

Attribution License (for details please see creativecommons.org), which permits unrestricted use, distribution, and reproduction in any medium, provided the original author and source are credited.

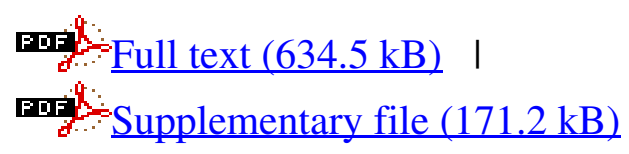

